\title{
PTR3: An Instrument for Studying the Lifecycle of Reactive Organic Carbon in the Atmosphere
}

\author{
Martin Breitenlechner, ${ }^{\S, \dagger}$ Lukas Fischer, ${ }^{\| \dagger}$ Markus Hainer, ${ }^{\dagger}$ Martin Heinritzi, ${ }^{\ddagger}$ Joachim Curtius, ${ }^{\dagger}$ \\ and Armin Hansel ${ }^{*}+{ }^{\dagger}$ \\ ${ }^{\dagger}$ Institute for Ion Physics and Applied Physics, University of Innsbruck, Technikerstraße 25, 6020 Innsbruck, Austria \\ ${ }^{*}$ Institute for Atmospheric and Environmental Sciences, Goethe University Frankfurt am Main, Altenhöferallee 1, 60438 Frankfurt am \\ Main, Germany
}

\section{Supporting Information}

ABSTRACT: We have developed and characterized the novel PTR3, a proton transfer reaction-time-of-flight mass spectrometer (PTR-TOF) using a new gas inlet and an innovative reaction chamber design. The reaction chamber consists of a tripole operated with rf voltages generating an electric field only in the radial direction. An elevated electrical field is necessary to reduce clustering of primary hydronium $\left(\mathrm{H}_{3} \mathrm{O}^{+}\right)$and product ions with water molecules present in the sample gas. The axial movement of the ions is achieved by the sample gas flow only. Therefore, the new design allows a 30-fold longer reaction time and a 40-fold increase in pressure compared to standard PTRTOF-MS. First calibration tests show sensitivities of up to 18000 counts per second/parts per billion and volume (cps/ppbv) at a

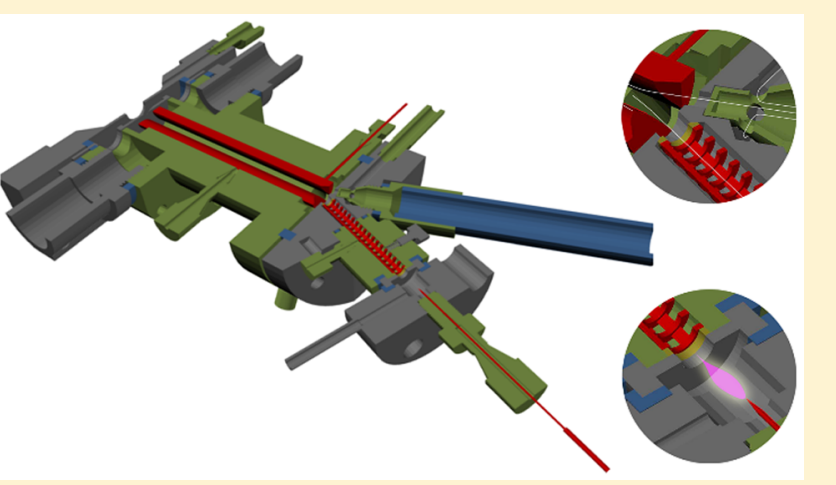
mass resolution of $>8000 \mathrm{~m} / \Delta m(\mathrm{fwhm})$. The new inlet using center-sampling through a critical orifice reduces wall losses of low volatility compounds. Therefore, the new PTR3 instrument is sensitive to VOC typically present in the ppbv range as well as to semivolatile organic compounds (SVOC) and even highly oxidized organic molecules (HOMs) present in the parts per quadrillion per volume (ppqv) range in the atmosphere.

$\mathrm{T}$ errestrial plants emit a large amount of volatile organic compounds (VOC) to the atmosphere. Their condensable oxidation products can form secondary organic aerosol (SOA), a significant component of atmospheric aerosol ${ }^{1,2}$ which is known to affect the Earth's radiation balance by backscattering solar radiation and by acting as cloud condensation nuclei (CCN). The quantitative assessment of such climate effects is poorly understood by a number of factors, including an incomplete understanding of how biogenic VOCs contribute to the formation of atmospheric secondary organic aerosol (SOA) and new particle formation (NPF). Just recently pure organic nucleation of $\alpha$-pinene oxidation products, the most abundant biogenic monoterpene, and water in laboratory experiments was observed for the first time. ${ }^{3,4}$ Autoxidation via $\mathrm{H}$-shift chemistry of peroxy radicals may play an important role in the oxidation of organic compounds in the atmosphere ${ }^{5}$ and thus in pure organic NPF. ${ }^{4}$ This process is a promising route to explain fast oxidation of endocyclic monoterpenes, which results in the formation of highly oxygenated molecules $(\mathrm{HOMs})^{6-8}$ spanning over several volatility classes including extremely low and low volatility, and even some semivolatile organic compounds (extremely low volatile organic compounds (ELVOC), low volatile organic compounds (LVOC), and semivolatile organic compounds $\left.(\mathrm{SVOC})^{9,10}\right)$. ELVOC can be experimentally measured and quantified by chemical ionization mass spectrometry (CIMS). For example nitrate ions $\left(\mathrm{NO}_{3}^{-}\right)$efficiently cluster with extremely low volatility compounds as shown from quantum chemical calculations, ${ }^{11}$ but the detection efficiency of this method decreases dramatically for less oxidized organic compounds having higher volatility., ${ }^{9,11,12}$ Recently several different chemical ionization methods evolved such as the $\mathrm{CF}_{3} \mathrm{O}^{-}$CIMS for specific detection of oxygenated VOC and SVOC such as hydroperoxides, ${ }^{13}$ the acetate negative CIMS for selective detection of organic acids, ${ }^{14,15}$ and the iodide adduct ionization CIMS for the detection of more general oxygenated organic compounds. ${ }^{16}$ These instruments based on negative ion chemistry make oxygenated gas phase compounds detectable even below 1 parts per trillion per volume (pptv).

Proton transfer reaction is another soft ionization technique which has been used since the mid 1990s, when this technique was developed by scientists in Innsbruck. ${ }^{17,18}$ The PTR-MS technique has been improved in terms of sensitivity, detection limit and by introducing the PTR-TOF-MS in the $2000 \mathrm{~s}^{19,20}$ that separates isobaric compounds due to a higher mass resolving power. The latest commercial PTR-TOF-MS instru-

Received: December 25, 2016

Accepted: April 24, 2017

Published: April 24, 2017 
ments use high resolution time-of-flight mass spectrometers, achieving sensitivities of up to 4000 counts per second/parts per billion and volume (cps/ppbv) and detection limits as low as 1 pptv $\left(3 \sigma, 1\right.$ min integration time). ${ }^{21}$ Existing PTR-TOF ${ }^{20}$ instruments are known to detect VOC and could in principle also detect highly oxidized organic compounds such as LVOC and ELVOC but PTR-TOF-MS inlets were not optimized to avoid wall losses of such low volatility compounds. In addition, PTR-TOF-MS is not sensitive enough to quantify second order and even higher order oxidation products at atmospherically relevant concentrations. To solve this problem, as well as to enable bridging the gap in understanding how atmospherically relevant BVOC form SVOC, LVOC, and even ELVOC, we developed the PTR3, a compact and field deployable ultrasensitive instrument described here.

PTR-MS uses either proton transfer or ligand switching from the hydronium ion $\left(\mathrm{H}_{3} \mathrm{O}^{+}\right)$water clusters to softly ionize a VOC, yielding predominantly $(\mathrm{VOC} \cdot \mathrm{H})^{+}$product ions (eq 1 ).

$$
\mathrm{H}_{3} \mathrm{O}^{+}\left(\mathrm{H}_{2} \mathrm{O}\right)_{n}+\mathrm{VOC} \rightarrow \mathrm{VOC} \cdot \mathrm{H}^{+}+\left(\mathrm{H}_{2} \mathrm{O}\right)_{n+1}
$$

A great advantage is that the major constituents of air have proton affinities lower than that of $\mathrm{H}_{2} \mathrm{O}$ and are thus unreactive to $\mathrm{H}_{3} \mathrm{O}^{+}$. Water has a proton affinity of $7.22 \mathrm{eV}$ whereas common VOC have proton affinities ranging from 7 to $9 \mathrm{eV} .{ }^{22}$ A key aspect of PTR-MS instruments is the use of an elevated $E / N$ ( $E$ being the electric field strength and $N$ the sample gas number density), which is necessary to reduce clustering of primary and product ions with water molecules present in the sample gas. At standard PTR-MS operation conditions an $E / N$ of typically $120 \mathrm{Td}$ ( 1 Townsend equals $10^{-17} \mathrm{~V} \mathrm{~cm}^{2}$ ) is applied limiting the amount of hydronium water clusters $\mathrm{H}_{3} \mathrm{O}^{+}\left(\mathrm{H}_{2} \mathrm{O}\right)_{n}$ for $n \geq 1$ to less than $10 \%$ of the total primary ion signal using ambient air as sample gas. ${ }^{23}$ One disadvantage of using a standard drift tube ${ }^{17-21,23,24}$ where the electrical field is parallel to the sample gas flow is the reduced reaction time of approximately $100 \mu \mathrm{s}$ (due to the necessary ion velocity of roughly $1000 \mathrm{~m} / \mathrm{s}$ needed to achieve collision energies high enough to avoid clustering).

\section{INSTRUMENT DESCRIPTION}

Here we present a new concept that decouples the direction of the high-energy collisions (radial) from the flow direction (axial) of the sample gas. This is achieved with a new tripole reaction chamber configuration shown in Figure 1. The ions'

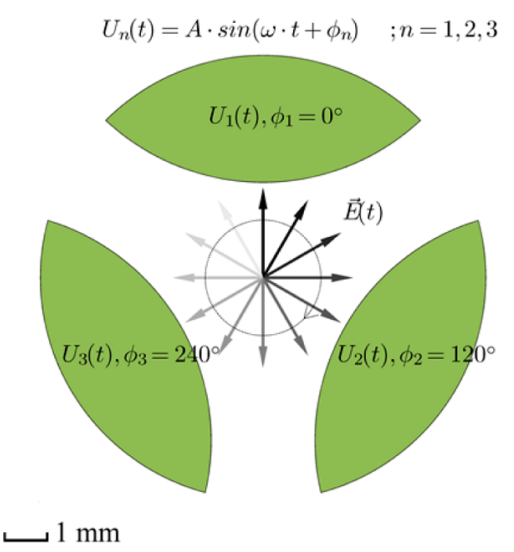

Figure 1. Sectional view of the PTR3 tripole. The electric field vector accelerating the ions rotates in the radial direction. axial velocities are decoupled from the electric field direction creating the necessary $E / N$ : collisional energy is induced by a rotating electric field vector generated by three electrodes surrounding the reaction region, each supplied with a radio frequency (rf) sinusoidal voltage, phase shifted by $120^{\circ}$, respectively. This effect can be achieved with any higher order multipole with $n$ rods phase shifted by $360^{\circ} / n$. In a threephase device, the simplest variant of multiphase-multipoles, ions experience constant collision energies in analogy to ions moving in a drift tube. However, now the reaction time is solely determined by the flow velocity of the sample gas in the axial direction.

The gained ability to choose reaction time, pressure, and reduced electric field strength independently from each other enabled the rethinking of the instruments' key operational parameters. The product of reaction time and pressure defines not only the sensitivity per unit primary ion current (known as the normalized sensitivity) but also the upper limit of total VOC concentrations which can be analyzed: secondary reactions (i.e., reactions with already protonated species with other VOC) must be kept at acceptable low rates compared to primary reaction rates and depletion of primary ions should not hinder quantification capabilities of the instrument under typical operation conditions. We defined a $10 \%$ primary ion loss as being acceptable at a total VOC volume mixing ratio of $50 \mathrm{ppbv}$ assuming a reaction rate constant of $3 \times 10^{-9} \mathrm{~cm}^{3} / \mathrm{s}$, corresponding to $240 \mathrm{mbar} \mathrm{ms}$ or an approximately 1000 -fold increase in sensitivity compared to classical PTR-MS (0.23 mbar ms).

The dimensions of the tripole are $3.5 \mathrm{~mm}$ incircle diameter and a length of $70 \mathrm{~mm}$. At an operation pressure of $80 \mathrm{mbar}$ and a sample gas flow rate in axial direction of 1 standardized liters per minute $(\mathrm{slpm})$, the resulting reaction time is $3 \mathrm{~ms}$ (assuming fully developed laminar flow with $v_{\max }=1.5 v_{\text {mean }}$ as an approximation). This is an increase in reaction time of 30 times compared to standard PTR-MS. In order to achieve elevated collision energies of the ions in radial directions corresponding to an $E / N$ of $120 \mathrm{Td}$ compared to standard PTR-MS at 50 mbar, rf amplitudes of less than $1000 \mathrm{~V}_{\mathrm{p} \text {-p }}$ are sufficient.

Ion trajectories in the tripole were obtained from SIMION $8.0^{25}$ simulations. Two types of ion trajectory models were used: first a viscous drag model and second a modified hard sphere collision model. ${ }^{25}$ For the drag model, a reduced mobility of $2.78 \mathrm{~cm}^{2} /(\mathrm{V} \mathrm{s})$ for $\mathrm{H}_{3} \mathrm{O}^{+}$and $0.70 \mathrm{~cm}^{2} /(\mathrm{V} \mathrm{s})$ for an ion with $m / z=200$ was used. ${ }^{26,27}$ The hard sphere collision model was adjusted for collision cross sections obtained from the Langevin ${ }^{28}$ equation that accurately describes collisions between ions and polarizable molecules such as nitrogen and oxygen. Simulations using the latter model were performed to optimize the geometry and the voltage settings of the instrument to maximize ion transmission efficiency. The result from the drag model shows the micro motion of ions within the tripole (Figure 2): an ion being in the center of the tripole is following a circle, whereas an ion located $0.5 \mathrm{~mm}$ off the center moves in an ellipse with one of its major radii facing the closest electrode. An rf frequency of $10 \mathrm{MHz}$ ensures that the radii of the ion's micromotion are very small compared to the diameter of the tripole $(3.5 \mathrm{~mm})$ and the diameter of the tripole exit lens $(0.6 \mathrm{~mm})$. The radii are on the order of $0.01 \mathrm{~mm}$ for $\mathrm{H}_{3} \mathrm{O}^{+}$ions and get even smaller for heavier ions due to their decreased mobility. In order to investigate the mass dependent ion transmission of the tripole, we simulated the fraction of ions 


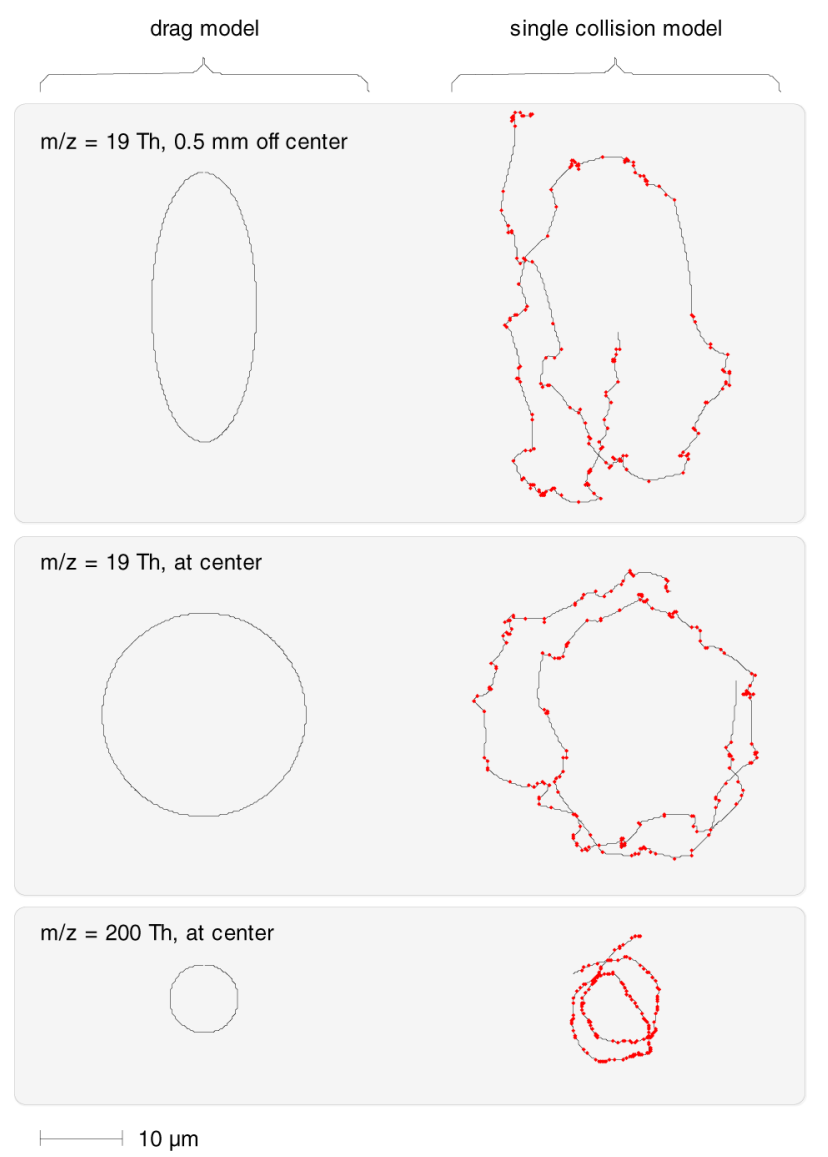

Figure 2. Simulated ion trajectories of $\mathrm{H}_{3} \mathrm{O}^{+}$ions $(m / z=19 \mathrm{Th})$ and an ion with $m / z=200 \mathrm{Th}$ in the tripole showing the micro motion. Ions were simulated at the center of the tripole and $0.5 \mathrm{~mm}$ off center (toward a pole). Two simple ion-gas collision models were compared: a viscous drag model to investigate the micro motion theoretically and a hard sphere collision model. ${ }^{25}$ Red dots mark single collisions with either $\mathrm{N}_{2}$ or $\mathrm{O}_{2}$ (dry air). Simulation parameters: rf frequency, 10 $\mathrm{MHz}$; rf amplitude, $240 \mathrm{~V}_{0 \text {-p }}$; pressure, $50 \mathrm{mbar}$; temperature, $300 \mathrm{~K}$; $E / N, 120 \mathrm{Td}$ at the center. At an rf frequency of $10 \mathrm{MHz}$, ions fulfill one full circle within $0.1 \mu \mathrm{s}$ resulting in 30000 full circles during the typical reaction time of $3 \mathrm{~ms}$.

reaching the exit lens of the tripole. Our simulations reveal a transmission efficiency of $25 \%$ at $\mathrm{m} / z 19$, while for $\mathrm{m} / z>100$ ions more than $75 \%$ are transmitted. This simulation result is further supported by the experiment. Switching off the rf field also increases the amount of detected light ions, e.g., $\mathrm{m} / \mathrm{z} 30$ relative to more heavy ions $m / z>100$ by a factor of 3 . Figure 3 shows the temporal oscillation of the $E / N$ value as a function of the distance from the center. The ion density was obtained by simulating ions using the hard sphere collision model, recording their positions throughout the tripole and fitting the radial ion density with a Gaussian model. A total of $90 \%$ of the ions exhibit a nonuniformity of the electric field strength below $25 \%$ of its mean value. This is comparable with standard PTR drift tubes, where a spatial variation of $15 \%$ in the field axis is observed, due to the ratio of the inner diameter $(12 \mathrm{~mm})$ and the axial distance $(10 \mathrm{~mm})$ between the drift rings.

The PTR3 ion source consists of a corona discharge and a source drift region to transfer primary ions to the tripole as shown in Figure 4. The source drift region with a total length of $25 \mathrm{~mm}$ is constructed from 15 drift rings (stainless steel, inner diameter $2.5 \mathrm{~mm}$, thickness $1.5 \mathrm{~mm}$ ) stacked with three surface

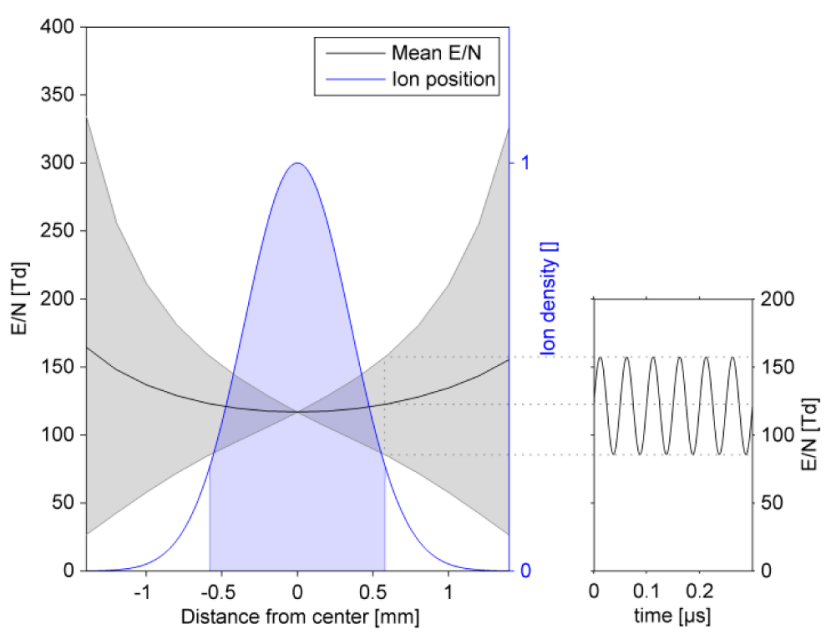

Figure 3. Simulation of mean $E / N$ values (solid black line) and corresponding minimum/maximum $E / N$ values (top and bottom of the gray area) over one $\mathrm{rf}$ period. The blue line represents the hydronium ion $(m / z=19)$ density distribution, averaged over the whole length of the tripole. The blue shaded area represents $90 \%$ of the area of the Gaussian fit, on its boundaries an oscillation of $30 \mathrm{Td}$ around $124 \mathrm{Td}$ occurs (equal a $25 \%$ variation).

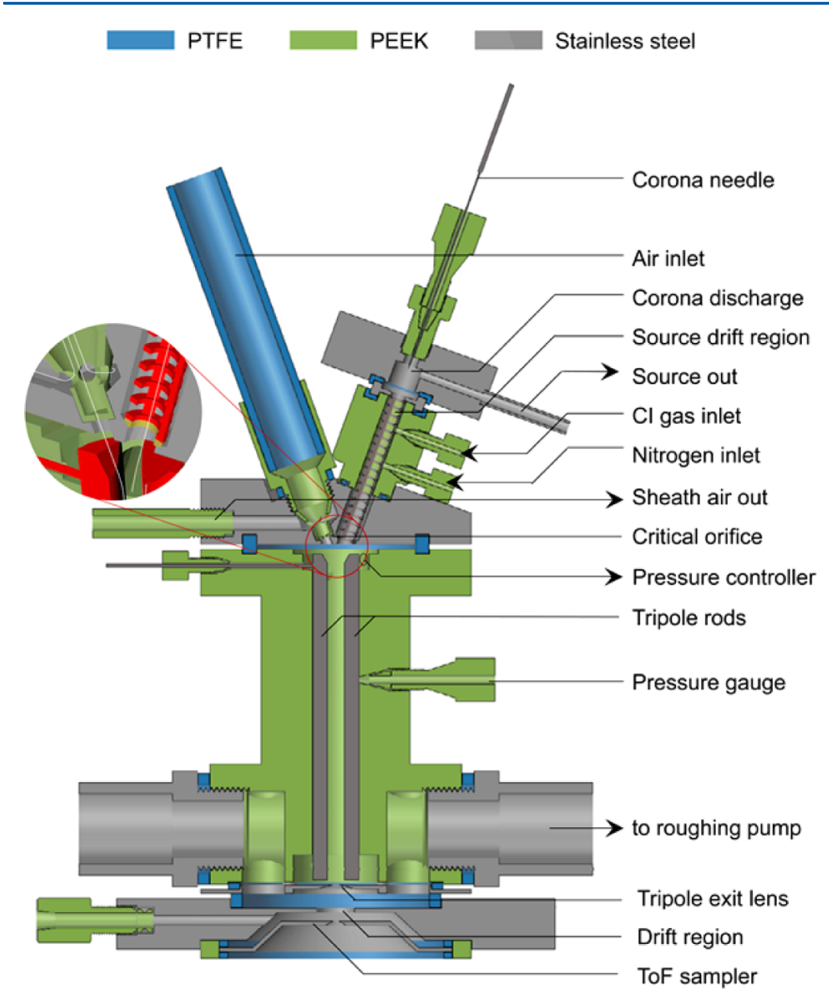

Figure 4. Schematic representation of the PTR3 front part. The insert shows a zoom-in of the inlet region. Typical flow rates are as follows: total sample gas inlet, $10 \mathrm{slpm}$; sheath air out, $8 \mathrm{slpm}$; CI gas inlet, 20 $\mathrm{sccm}$; nitrogen inlet, $80 \mathrm{sccm}$; source out, $50 \mathrm{sccm}$; into mass spectrometer through sampler (not shown), $20 \mathrm{sccm}$; to roughing pump, 1 slpm. Typical pressures: source drift region and tripole region, 80 mbar; drift region, 4 mbar.

mount device (SMD) resistors in parallel between each ring acting as spacer and voltage divider cascade at the same time. The overall resistance is $5 \mathrm{M} \Omega$, allowing a high electric field of approximately $1 \mathrm{kV} / \mathrm{cm}$ at $80 \mathrm{mbar}$, corresponding to an $E / N$ of $50 \mathrm{Td}$. The source drift region is split into two sections, as 
illustrated in Figure 5. Nitrogen as an inert carrier gas is introduced at the middle of the source drift region. In close

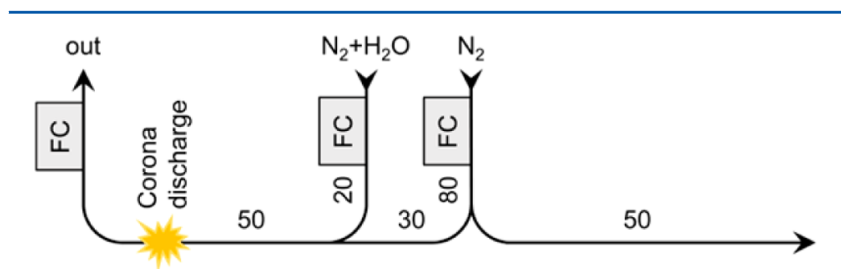

Figure 5. Schematic representation of the gas flows in the ion source, showing the $\mathrm{N}_{2}$ inlet, the $\mathrm{CI}$ gas $\left(\mathrm{H}_{2} \mathrm{O}\right.$ in $\left.\mathrm{N}_{2}\right)$ inlet, and the source outlet, respectively. The three mass flow controllers (FC) help to achieve the flow rates given in sccm.

proximity, the chemical ionization (CI) gas, usually humidified nitrogen is added to the system. A mass flow controller draws a constant flow of 50 standardized $(T=273.15 \mathrm{~K}, p=1013$ mbar) cubic centimeters per minute $(\mathrm{sccm})$ behind the plasma, and as a result, the remaining $50 \mathrm{sccm} \mathrm{N}_{2}$ are transported toward the tripole. The resulting split flow architecture on the one hand prevents sample gas present in the tripole to reach the plasma zone (otherwise producing more unwanted primary ions such as $\mathrm{O}_{2}^{+}, \mathrm{NO}^{+}$, etc.) and on the other hand radicals (e.g., $\mathrm{OH}$ ) produced in the plasma zone to reach the tripole. These radicals would otherwise undergo chemical reactions with analyte molecules present in the sample gas, leading to artificial production of oxidation products.

The sample gas inlet consists of a 3/8 in. PTFE (i.d. $7.5 \mathrm{~mm}$ ) tube with a flow rate of 10 slpm, which results in a Reynold's number of approximately 2000 being still laminar. A core flow of typically 2 slpm enters the reaction region via a critical orifice, while $8 \mathrm{slpm}$ are used as sheath gas. A pressure controller is used to maintain a constant pressure within the reaction region and draws approximately half of the orifice flow, so that $1 \mathrm{slpm}$ of sample gas finally flows through the tripole reaction region. The pressure controller draws air from the region between the critical orifice and the tripole, so that the actual flow through the pressure controller does not influence the reaction time. Small lateral bores in close proximity to the critical orifice ensure that the sheath gas is pumped out symmetrically around the core flow entering the instrument to minimize wall contact of the sample gas. This core-sampling approach is essential to minimize wall losses of LVOC and ELVOC and allows quantitative analytical analysis of readily adsorbing molecules. The gas flow through the tripole exit lens (Figure 4) leads to a pressure drop from 80 mbar to 4 mbar in the drift region preparing the coupling of the PTR3 to a single quadrupole interfaced LTOF mass spectrometer (TOFWERK AG, Thun, Switzerland). In this region, ions' (micro-) motions are dominated by the electric field at $4 \mathrm{mbar}$ as is the case in a standard PTR-MS drift tube. The time ions spend in this region (typically $20 \mu \mathrm{s}$ ) and the numbers of collisions with the sample gas molecules is small compared to the overall reaction time but sufficiently long to establish a primary and product ion water cluster distribution different from the distribution in the tripole reaction region. In addition, the observed primary ion distribution is influenced by the quadrupole interface of the mass spectrometer, mostly by suppressing the signal intensity of light ions such as $m / z=21.0221\left(\mathrm{H}_{3}{ }^{18} \mathrm{O}^{+}\right)$due to the low-mass cutoff of rf-only ion guides. ${ }^{29,30}$

\section{FIRST LABORATORY RESULTS}

In the first laboratory study we obtained ion intensities summarized in Table 1 . The most abundant impurity ions are

Table 1. Primary Ion Intensities

\begin{tabular}{lcrrr} 
& & \multicolumn{3}{c}{ ion intensities } \\
\cline { 3 - 5 } \multicolumn{1}{c}{ ion formula } & $m / z[\mathrm{Th}]$ & \multicolumn{1}{c}{$\mathrm{cps}^{a}$} & $\mathrm{dcps}^{b}$ & percent $^{b}$ \\
$\mathrm{H}_{3} \mathrm{O}^{+}$ & 21.0221 & 80500 & 175600 & \\
$\mathrm{H}_{3} \mathrm{O}^{+} \cdot \mathrm{H}_{2} \mathrm{O}$ & 39.0327 & 422250 & 675900 & \\
$\mathrm{H}_{3} \mathrm{O}^{+} \cdot\left(\mathrm{H}_{2} \mathrm{O}\right)_{2}$ & 55.0390 & 250 & 330 & \\
total primary ions & & 503000 & 851800 & $100 \%$ \\
$\mathrm{O}_{2}{ }^{+}$ & 31.9893 & 5370 & 9500 & $1.1 \%$ \\
$\mathrm{NO}^{+}$ & 29.9974 & 5550 & 10140 & $1.2 \%$ \\
$\mathrm{NH}_{4}{ }^{+}$ & 18.0338 & 1400 & 3300 & $0.39 \%$ \\
$\mathrm{NO}_{2}{ }^{+}$ & 45.9924 & 22 & 32 & $0.004 \%$
\end{tabular}

${ }^{a}$ Calculated from isotopic masses listed. ${ }^{b}$ Duty-cycle corrected relative to $m / z=100.0$.

$\mathrm{NO}^{+}$and $\mathrm{O}_{2}^{+}$. Note that their relative abundance is also influenced by the low-mass cutoff of the quadrupole ion guide. Since both the reaction time (exact flow profile) and the transmission efficiency of primary ions relative to product ions is not well-defined in our setup, we rely on calibrations using gas standards to determine the product $t \cdot p \cdot I$ (reaction time . reaction pressure $\cdot$ primary ion intensity) necessary to quantify compounds with known reaction rate constants.

\section{CALIBRATION}

In Figure 6 we present sensitivities of acetone, hexanone, acetonitrile, and $\alpha$-pinene obtained from dynamically diluting a
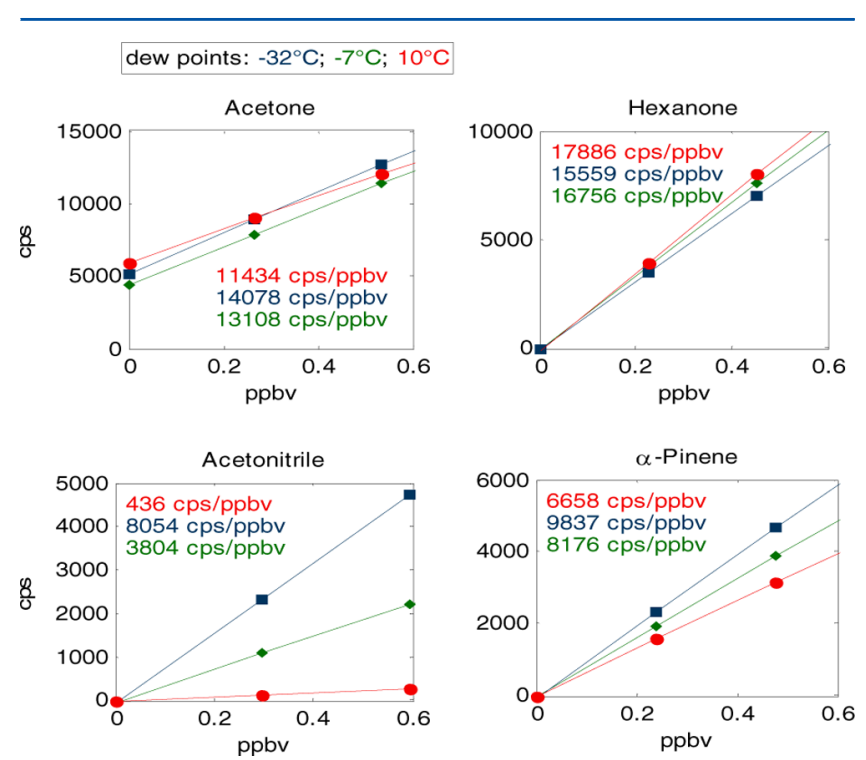

Figure 6. Sensitivities of acetone, hexanone, acetonitrile, and $\alpha$-pinene at different relative humidities.

multi component gas standard (Apel-Riemer Environmental Inc., $\mathrm{CO}$ ) into VOC-free air at three different humidities. VOCfree air was generated by flowing ambient air through a catalytic converter (HPZA-7000, Parker Hannifin Co, MA). The offset of approximately $5000 \mathrm{cps}(\sim 400 \mathrm{pptv})$ for acetone is ascribed to incomplete removal by the catalytic converter operated at its maximum flow rate $(7 \mathrm{slpm})$. Sensitivities are reported for measured counts per second observed at $\mathrm{m} / z=59.0491$ for 
Table 2. Sensitivities Analyzing a Multicomponent Gas Standard (Apel-Riemer Environmental Inc., CO) ${ }^{a}$

\begin{tabular}{|c|c|c|c|c|c|c|c|c|c|}
\hline \multirow[b]{2}{*}{ substance } & \multirow[b]{2}{*}{ sum formula } & \multirow[b]{2}{*}{$m / z[\mathrm{Th}]$} & \multirow[b]{2}{*}{$\mathrm{PA}[\mathrm{kJ} / \mathrm{mol}]$} & \multicolumn{3}{|c|}{ sensitivity $[\mathrm{dcps} / \mathrm{ppbv}]$} & \multicolumn{3}{|c|}{$2 \sigma$-LOD [pptv] $(1 \mathrm{~s})$} \\
\hline & & & & DP: $-32{ }^{\circ} \mathrm{C}$ & $-7{ }^{\circ} \mathrm{C}$ & $10^{\circ} \mathrm{C}$ & DP: $-32{ }^{\circ} \mathrm{C}$ & $-7^{\circ} \mathrm{C}$ & $10^{\circ} \mathrm{C}$ \\
\hline formaldehyde & $\mathrm{CH}_{2} \mathrm{OH}^{+}$ & 31.0178 & 713 & 10 & 9 & 7 & 740 & 710 & 1100 \\
\hline methanol & $\mathrm{CH}_{4} \mathrm{OH}^{+}$ & 33.0335 & 754 & 4902 & 557 & 44 & 5 & 14 & 79 \\
\hline acetonitrile & $\mathrm{C}_{2} \mathrm{H}_{3} \mathrm{NH}^{+}$ & 42.0338 & 779 & 12423 & 5868 & 673 & 0.68 & 0.92 & 2.5 \\
\hline acetaldehyde & $\mathrm{C}_{2} \mathrm{H}_{4} \mathrm{OH}^{+}$ & 45.0335 & 769 & 675 & 184 & 152 & 35 & 43 & 70 \\
\hline 2-propenal & $\mathrm{C}_{3} \mathrm{H}_{4} \mathrm{OH}^{+}$ & 57.0335 & 797 & 14832 & 12146 & 1902 & 0.43 & 0.56 & 8.2 \\
\hline acetone & $\mathrm{C}_{3} \mathrm{H}_{6} \mathrm{OH}^{+}$ & 59.0491 & 812 & 18320 & 17058 & 14879 & 8.9 & 8.8 & 12 \\
\hline \multirow[t]{2}{*}{ isoprene } & $\mathrm{C}_{5} \mathrm{H}_{8} \mathrm{H}^{+}$ & 69.0699 & & 7752 & 4440 & 2441 & 0.75 & 2.1 & 1.8 \\
\hline & $\mathrm{C}_{3} \mathrm{H}_{4} \mathrm{H}^{+}$ & 41.0386 & & 394 & 218 & 101 & 17 & 28 & 59 \\
\hline isoprene total & & & 826 & 8145 & 4658 & 2542 & 1.3 & 2.9 & 3.5 \\
\hline 2-butanone & $\mathrm{C}_{4} \mathrm{H}_{8} \mathrm{OH}^{+}$ & 73.0648 & 827 & 17354 & 15754 & 16529 & 0.92 & 0.58 & 0.54 \\
\hline benzene & $\mathrm{C}_{6} \mathrm{H}_{6} \mathrm{H}^{+}$ & 79.0542 & 750 & 872 & 13 & 4 & 2.4 & 140 & 690 \\
\hline toluene & $\mathrm{C}_{7} \mathrm{H}_{8} \mathrm{H}^{+}$ & 93.0699 & 784 & 4329 & 435 & 15 & 0.83 & 7.9 & 270 \\
\hline 3-hexanone & $\mathrm{C}_{6} \mathrm{H}_{12} \mathrm{OH}^{+}$ & 101.0961 & 843 & 15475 & 16665 & 17788 & 0.43 & 0.88 & 0.23 \\
\hline$p$-xylene & $\mathrm{C}_{8} \mathrm{H}_{10} \mathrm{H}^{+}$ & 107.0855 & 794 & 16207 & 6285 & 367 & 0.21 & 0.47 & 21 \\
\hline \multirow[t]{2}{*}{$\alpha$-pinene } & $\mathrm{C}_{10} \mathrm{H}_{16} \mathrm{H}^{+}$ & 137.1325 & & 6250 & 5233 & 4375 & 0.57 & 0.80 & 0.82 \\
\hline & $\mathrm{C}_{6} \mathrm{H}_{8} \mathrm{H}^{+}$ & 81.0699 & & 2797 & 2275 & 1704 & 1.7 & 1.9 & 3.0 \\
\hline$\alpha$-pinene total & & & 879 & 9047 & 7508 & 6079 & 0.61 & 0.73 & 0.94 \\
\hline
\end{tabular}

acetone, $m / z=101.0961$ for 3-hexanone, $m / z=42.0338$ for acetonitrile, and the sum of $m / z=81.0699$ and $m / z=137.1325$ for $\alpha$-pinene, respectively. The dew points correspond to $38 \%$ relative humidity at temperatures of $-32{ }^{\circ} \mathrm{C},-7^{\circ} \mathrm{C}$, and +10 ${ }^{\circ} \mathrm{C}$, respectively. Table 2 shows the obtained sensitivities of all 13 VOCs present in the gas standard. Proton affinities (PA) are from Hunter and Lias, ${ }^{31}$ duty cycle corrected counts per second (dcps, normalized to $m / z=100$ ) are given in order to compensate for the mass-dependent transmission of the TOF mass spectrometer $\left(\operatorname{dcps}(i)=\operatorname{cps}(i) \cdot \sqrt{100 / m_{i}}\right.$. Limits of Detection (LOD) are calculated for $1 \mathrm{~s}$ integration time as 2 times the standard deviation of measured chemical background divided by the measured sensitivity. Experimental conditions: reaction pressure, $83 \mathrm{mbar} ; \mathrm{E} / \mathrm{N}, 80 \mathrm{Td}$.

\section{ION CHEMISTRY AND WATER DEPENDENCE}

In classical PTR-MS, an E/N value of typically $120 \mathrm{Td}$ (at a drift pressure of $2-3 \mathrm{mbar}$ ) is applied to ensure that $\mathrm{H}_{3} \mathrm{O}^{+}$is the prevailing primary ion. For this case one primary ion, namely, $\mathrm{H}_{3} \mathrm{O}^{+}$reacts with a VOC forming $\mathrm{VOC} \cdot \mathrm{H}^{+}$. This pseudo first order reaction can be solved easily and sensitivity values can be calculated knowing the reaction rate constant for the proton transfer reaction, the reaction time, and pressure. ${ }^{17}$ For VOCs having only a slightly larger proton affinity than water, the reverse proton transfer reaction has to be taken into account. This was previously shown in detail ${ }^{22}$ for $\mathrm{HCHO}$ for which the reverse channel is endothermic by only $22 \mathrm{~kJ} / \mathrm{mol}$. Vlasenko et al. ${ }^{32}$ demonstrated that in a standard PTR-MS at 2 mbar the reaction time is too short to reach an equilibrium between forward and reverse proton transfer reactions. Therefore, the HCHO sensitivity is reduced by a rather small factor of about 10 under atmospherically relevant conditions. ${ }^{33}$ This is not any more valid for the PTR3 because the enhanced reaction time and the increased pressure ensure that equilibrium between forward and reverse proton transfer reactions is achieved. Simulating this situation using the measured forward and reverse reaction rate constants ${ }^{22}$ reveals a far more dramatic reduction in sensitivity by a factor of approximately 200 . Results for various parameters are shown in
Figure S1 and explain the observed PTR3 sensitivities of only about $9 \mathrm{dcps} / \mathrm{ppb}$ for HCHO. For more details see the Supporting Information.

Ketones show the highest sensitivities, which are almost independent of the dew point. It is well-known that ketones react efficiently with all hydronium water clusters while ligand switching is exothermic due to their high PA and their ability to form strong proton bound water clusters.

Benzene has a proton affinity of $750 \mathrm{~kJ} / \mathrm{mol}$ and reacts only with $\mathrm{H}_{3} \mathrm{O}^{+}$because ligand switching is not exothermic. ${ }^{34} \mathrm{We}$ therefore expect lower sensitivities with rising humidity in the sample air compared to, e.g., ketones, caused by two effects: first, the previously mentioned water dependent reverse reaction channel becomes relevant at PA close to the PA of water and second, more $\mathrm{H}_{3} \mathrm{O}^{+}$primary ions will cluster with water molecules and hence being not available for proton transfer reactions with benzene. According to Figure S1a, the sensitivity for a compound having a PA of $750 \mathrm{~kJ} / \mathrm{mol}$ like benzene should be almost unaffected by the reverse reaction under dry conditions $\left(-32{ }^{\circ} \mathrm{C}\right.$ dew point). The calibration results from Table 2 also show $872 \mathrm{dcps} / \mathrm{ppbv}$ in contrast to, e.g., 2-butanone, which has a sensitivity of $17354 \mathrm{dcps} / \mathrm{ppb}$ at a dew point of $-32{ }^{\circ} \mathrm{C}$. This indicates that only a minor amount of the primary ions is present as $\mathrm{H}_{3} \mathrm{O}^{+}$in the tripole, even under dry conditions.

Sensitivities for different compound classes including hydrocarbons (benzene, toluene, xylene, isoprene, $\alpha$-pinene), alcohols (methanol), aldehydes (formaldehyde, acetaldehyde, 2-propanal), ketones (acetone, 2-propanone, 3-hexanone), and acetonitrile could theoretically be explained by their respective proton affinities and ability to form proton bound water clusters in accordance with Yuan et al. ${ }^{35}$ Unfortunately the true primary ion water cluster distribution is not directly measurable, because collision induced dissociation after the tripole changes it before the TOF measurement. In addition, the ability of a compound to perform exothermic ligand switching with different hydronium water clusters depends on the proton affinity and/or dipole moment of the compound. Careful calibration over a broad humidity range will be necessary, especially for compounds with only slightly higher 

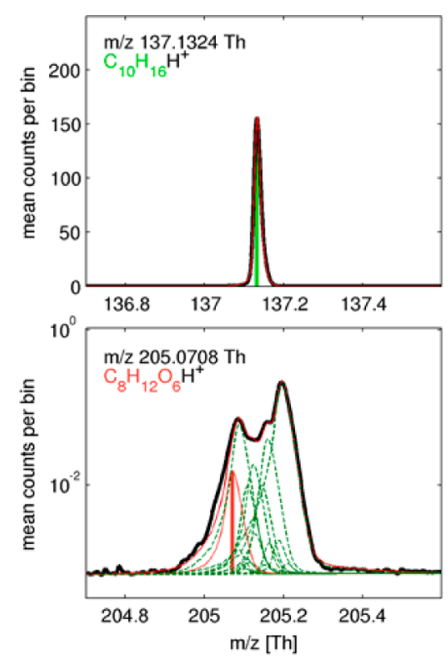
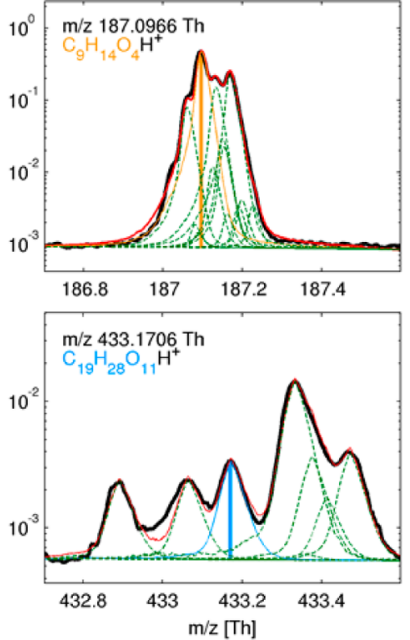

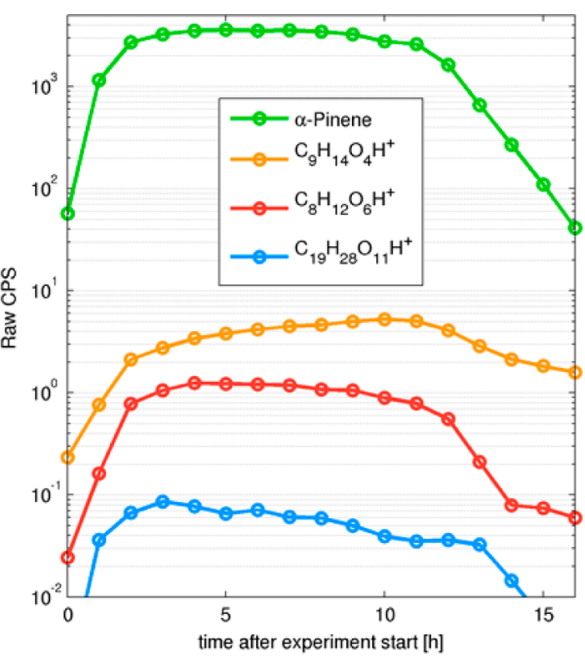

Figure 7. Mass spectra (left) were obtained during an ozonolysis experiment with $\alpha$-pinene as precursor. Ion signals were averaged over a $24 \mathrm{~h}$ period for peak assignment. The time series plot (right) shows the time evolution of individual masses separated by multipeak fitting with an averaged time resolution of one point per hour. The data were obtained at the CLOUD chamber at CERN.

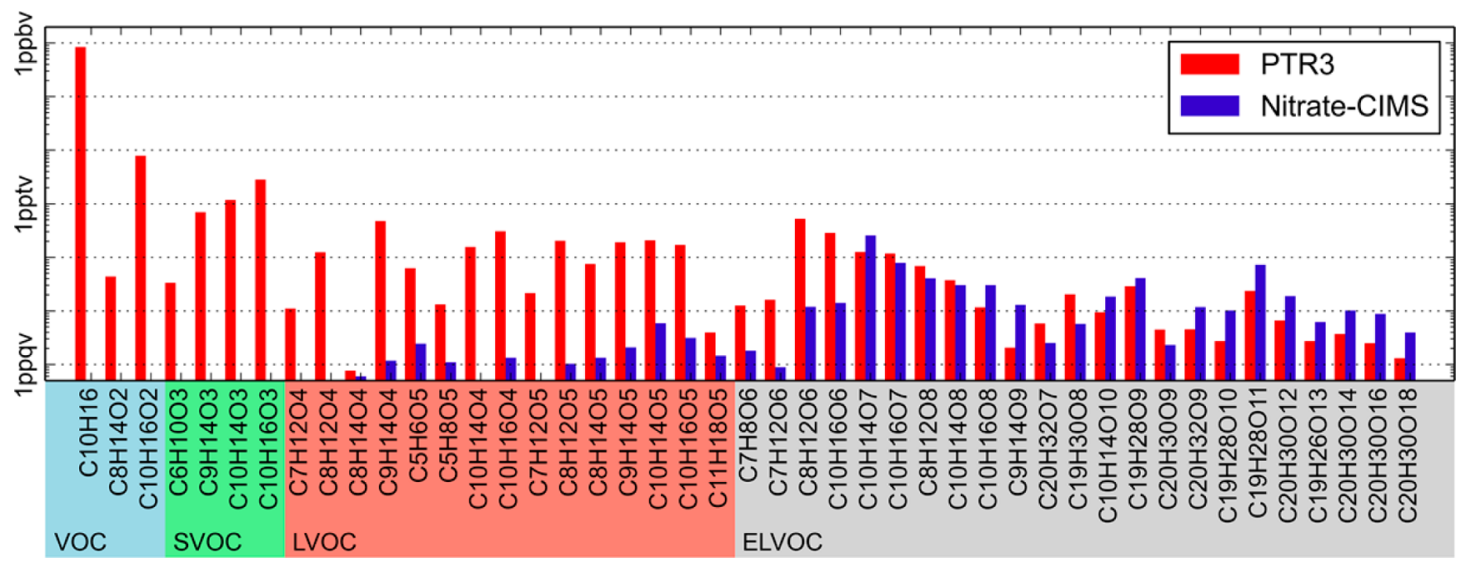

Figure 8. PTR3 (in red) and nitrate CI-API-TOF (in blue) results from an ozonlysis experiment of 1 ppb $\alpha$-pinene and 40 ppb ozone at the CLOUD chamber at $5{ }^{\circ} \mathrm{C}$ and a relative humidity of $38 \%$. Exact masses were used to assign sum formulas that are organized as a function of saturation vapor pressure according to Donahue et al. ${ }^{36}$ ranging from VOC, SVOC, LVOC to ELVOC.

proton affinities than water and or small dipole moments such as hydrocarbons and less oxidized species. HOMs, however, are thought to be less affected by these issues, since different functional groups such as carbonyls, carboxylic acids, hydroxyls, and hydroperoxides are present offering more reactive sites for either direct proton transfer or exothermic ligand switching with hydronium water clusters. This is also in agreement with first intercomparison results from a CLOUD chamber experiment (see next paragraph) where we found very good agreement between PTR3 and nitrate CI-API-TOF measurements for LVOC and ELVOC produced from $\alpha$-pinene ozonolysis.

\section{FIRST CLOUD CHAMBER EXPERIMENTS}

The PTR3 was deployed to the CLOUD10 campaign (September-December 2015 at CERN; www.cern.ch/cloud). Here we present a comparison of the PTR3 with the nitrate-CIAPI-TOF from the University of Frankfurt during an ozonlysis experiment with $1 \mathrm{ppb} \alpha$-pinene and $40 \mathrm{ppb}$ ozone at the CLOUD chamber (gas exchange rate, $3 \mathrm{~h}$ ) at $5{ }^{\circ} \mathrm{C}$ and a relative humidity of $38 \%$.
PTR3 Data Processing. Chemical ionization utilizing $\mathrm{H}_{3} \mathrm{O}^{+}\left(\mathrm{H}_{2} \mathrm{O}\right)_{n}$ primary ions makes analysis of PTR3 raw data challenging with multiple peaks on every nominal mass. Therefore, we developed new tools for PTR3-TOF data analysis, including a multipeak fitting routine, which is used on long-term averaged, mass scale corrected spectral data to assign sum formulas to all detected peaks taking into account isotope patterns. The resulting mass list is subsequently used to extract interference free time traces for all observed mass peaks from raw data. On the left side of Figure 7, a mass scale corrected, $24 \mathrm{~h}$ time averaged spectrum with applied multi peak fitting is shown, the resulting time-resolved mass traces with one data point averaged over $1 \mathrm{~h}$ is shown on the right side of Figure 7. The exact mass peaks observed at $\mathrm{m} / z=137.1324 \mathrm{Th}$ correspond to the precursor $\alpha$-pinene, $m / z=187.0966$ is assigned to protonated $\mathrm{C}_{9} \mathrm{H}_{14} \mathrm{O}_{4}$, e.g., pinic acid, $m / z=$ 205.0708 is assigned to protonated $\mathrm{C}_{8} \mathrm{H}_{12} \mathrm{O}_{6}$, e.g., MBTCA (3methyl-1,2,3-butane tricarboxylic acid), $m / z=433.1706$ is assigned to protonated $\mathrm{C}_{19} \mathrm{H}_{28} \mathrm{O}_{11}$, a prominent "dimer" of $\alpha$ pinene oxidation. Figure 7 also demonstrates the importance of high mass resolving power for improving detection limits in the PTR3: High mass resolution not only reduces the influence of a 
given baseline signal but, even more importantly, also reduces the interference of neighboring peaks. ${ }^{37}$

For quantification and comparison with nitrate-CIMS, the following corrections were applied to the measured ion count rates: $\alpha$-pinene $\left(\mathrm{C}_{10} \mathrm{H}_{16}\right)$ was directly calibrated as described earlier. Together with systematic errors from the flow controllers, we conservatively estimate an accuracy of $10 \%$ for $\alpha$-pinene. For all oxidized species shown in Figure 8, the uncertainties become larger: We assumed that all oxidized compounds perform either proton transfer from $\mathrm{H}_{3} \mathrm{O}^{+}$or exothermic and thus fast ligand switching reactions with the hydronium water clusters forming protonated HOMs. We did not take into account possible fragmentation of HOMs, e.g., $\mathrm{H}_{2} \mathrm{O}$ loss. Therefore, we used the same sensitivity we obtained from 2-butanone calibration for all oxidized compounds. ELVOC have such a low saturation vapor pressure that every collision with the inlet wall or the tripole lead to a complete loss. We multiplied the ELVOC and LVOC signals having more than five oxygens with a factor of 5 assuming wall losses of $80 \%$. VOC, SVOC, and LVOC signals with less than 5 oxygens were not corrected for line losses. This is reasonable for VOC and SVOC because these compounds stay prevailingly in the gas phase. For some LVOC our assumption may lead to an underestimation.

Nitrate-CIMS Data Processing. The nitrate chemical ionization-atmospheric pressure interface (nitrate-CI-API) is operated with a corona discharge ion source at atmospheric pressure. $^{38}$ The instrument is calibrated with respect to sulfuric $\operatorname{acid}^{39}$ and corrected for ion transmission efficiency ${ }^{40}$ and sampling line losses. The charging efficiency for HOMs is assumed to be kinetically limited and similar as for sulfuric acid. ${ }^{7}$ For further details of HOM quantification, we refer the reader to Kirkby et al. ${ }^{4}$

Comparison. The observed volume mixing ratios range from 1 parts per quadrillion per volume (ppqv) to $1 \mathrm{ppbv}$ and were obtained as discussed above. Exact masses were used to assign sum formulas that are roughly categorized as a function of saturation vapor pressure according to Donahue et al. ${ }^{36}$ ranging from VOC, SVOC, LVOC to ELVOC. There is very good agreement for compounds having more than 6 oxygens. For less oxidized compounds, the nitrate-CI-API-TOF loses dramatically in sensitivity, meaning that this instrument is not sensitive for certain LVOC, SVOC, and VOC.

\section{CONCLUSION AND SUMMARY}

The first PTR3 prototype has sensitivities of up to $18000 \mathrm{cps} /$ ppbv and a mass resolution of approximately $8000 \mathrm{~m} / \Delta \mathrm{m}$. The instrument has been successfully calibrated and tested at CERN for the CLOUD 10 campaign in 2015, where low volatility organic compounds were measured. During pure $\alpha$-pinene ozonolysis experiments at low $\mathrm{NO}_{x}$ conditions, we observed in total 1000 peaks in the mass spectrum, including $\alpha$-pinene present in the ppbv range, first and higher order oxidation products present in the pptv range, and highly oxidized $\alpha$ pinene monomers and dimers in the low ppqv range. An intercomparison of PTR3 and the nitrate-CI-API-TOF shows very good agreement for highly oxidized ELVOC within a factor of 2. For less oxidized compounds, the nitrate-CI-APITOF has no sensitivity. With its broad coverage of detectable compounds from precursors to HOMs, the PTR3 will help to understand the formation of SVOC, LVOC, and even ELVOC from atmospherically relevant VOC.

\section{ASSOCIATED CONTENT}

\section{Supporting Information}

The Supporting Information is available free of charge on the ACS Publications website at DOI: 10.1021/acs.analchem.6b05110.

Calculation of humidity dependency and resulting figure of humidity dependency calculations (PDF)

\section{AUTHOR INFORMATION}

\section{Corresponding Author}

*E-mail: Armin.Hansel@uibk.ac.at.

ORCID $\odot$

Armin Hansel: 0000-0002-1062-2394

\section{Present Address}

${ }^{\S}$ M.B.: Harvard John A. Paulson School of Engineering and Applied Sciences, Harvard University, 12 Oxford Street, Cambridge, MA 02138.

\section{Author Contributions}

"M.B. and L.F. contributed equally.

\section{Notes}

The authors declare the following competing financial interest(s): Armin Hansel is co-founder and share holder of Ioicon Anaytik who might commercialize the PTR3.

\section{ACKNOWLEDGMENTS}

We thank Gabriel Colloselli for his assistance in electronics design and Gregor Mayramhof for his $\mathrm{C}++$ control software programming inputs. We thank the Austrian Research Funding Association (FFG, Project Number 846050) for financial support and IONICON Analytik GmbH for in-kind contributions within the project. M. Heinritzi and J.C. thank for funding from EC FP7 (MC-ITN CLOUD-TRAIN No. 316662) and the German BMBF (Project Nos. 01LK1222A and 01LK1601A).

\section{REFERENCES}

(1) Hallquist, M.; Wenger, J. C.; Baltensperger, U.; Rudich, Y.; Simpson, D.; Claeys, M.; Dommen, J.; Donahue, N. M.; George, C.; Goldstein, A. H.; Hamilton, J. F. Atmos. Chem. Phys. 2009, 9 (14), 5155-5236.

(2) Jimenez, J. L.; Canagaratna, M. R.; Donahue, N. M.; Prevot, A. S. H.; Zhang, Q.; Kroll, J. H.; DeCarlo, P. F.; Allan, J. D.; Coe, H.; Ng, N. L.; Aiken, A. C.; Docherty, K. S.; Ulbrich, I. M.; Grieshop, A. P.; Robinson, A. L.; Duplissy, J.; Smith, J. D.; Wilson, K. R.; Lanz, V. A.; Hueglin, C.; Sun, Y. L.; Tian, J.; Laaksonen, A.; Raatikainen, T.; Rautiainen, J.; Vaattovaara, P.; Ehn, M.; Kulmala, M.; Tomlinson, J. M.; Collins, D. R.; Cubison, M. J.; Dunlea, E. J.; Huffman, J. A.; Onasch, T. B.; Alfarra, M. R.; Williams, P. I.; Bower, K.; Kondo, Y.; Schneider, J.; Drewnick, F.; Borrmann, S.; Weimer, S.; Demerjian, K.; Salcedo, D.; Cottrell, L.; Griffin, R.; Takami, A.; Miyoshi, T.; Hatakeyama, S.; Shimono, A.; Sun, J. Y.; Zhang, Y. M.; Dzepina, K.; Kimmel, J. R.; Sueper, D.; Jayne, J. T.; Herndon, S. C.; Trimborn, A. M.; Williams, L. R.; Wood, E. C.; Middlebrook, A. M.; Kolb, C. E.; Baltensperger, U.; Worsnop, D. R.; Worsnop, D. R. Science 2009, 326 (5959), 1525-1529.

(3) Kirkby, J.; Curtius, J.; Almeida, J.; Dunne, E.; Duplissy, J.; Ehrhart, S.; Franchin, A.; Gagné, S.; Ickes, L.; Kürten, A.; Kupc, A.; Metzger, A.; Riccobono, F.; Rondo, L.; Schobesberger, S.; Tsagkogeorgas, G.; Wimmer, D.; Amorim, A.; Bianchi, F.; Breitenlechner, M.; David, A.; Dommen, J.; Downard, A.; Ehn, M.; Flagan, R. C.; Haider, S.; Hansel, A.; Hauser, D.; Jud, W.; Junninen, H.; Kreissl, F.; Kvashin, A.; Laaksonen, A.; Lehtipalo, K.; Lima, J.; Lovejoy, E. R.; Makhmutov, V.; Mathot, S.; Mikkilä, J.; Minginette, P.; 
Mogo, S.; Nieminen, T.; Onnela, A.; Pereira, P.; Petäjä, T.; Schnitzhofer, R.; Seinfeld, J. H.; Sipilä, M.; Stozhkov, Y.; Stratmann, F.; Tomé, A.; Vanhanen, J.; Viisanen, Y.; Vrtala, A.; Wagner, P. E.; Walther, H.; Weingartner, E.; Wex, H.; Winkler, P. M.; Carslaw, K. S.; Worsnop, D. R.; Baltensperger, U.; Kulmala, M. Nature 2011, 476 (7361), 429-433.

(4) Kirkby, J.; Duplissy, J.; Sengupta, K.; Frege, C.; Gordon, H.; Williamson, C.; Heinritzi, M.; Simon, M.; Yan, C.; Almeida, J.; Trostl, J.; Nieminen, T.; Ortega, I. K.; Wagner, R.; Adamov, A.; Amorim, A.; Bernhammer, A. K.; Bianchi, F.; Breitenlechner, M.; Brilke, S.; Chen, X. M.; Craven, J.; Dias, A.; Ehrhart, S.; Flagan, R. C.; Franchin, A.; Fuchs, C.; Guida, R.; Hakala, J.; Hoyle, C. R; Jokinen, T.; Junninen, H.; Kangasluoma, J.; Kim, J.; Krapf, M.; Kurten, A.; Laaksonen, A.; Lehtipalo, K.; Makhmutov, V.; Mathot, S.; Molteni, U.; Onnela, A.; Perakyla, O.; Piel, F.; Petaja, T.; Praplan, A. P.; Pringle, K.; Rap, A.; Richards, N. A. D.; Riipinen, I.; Rissanen, M. P.; Rondo, L.; Sarnela, N.; Schobesberger, S.; Scott, C. E.; Seinfeld, J. H.; Sipila, M.; Steiner, G.; Stozhkov, Y.; Stratmann, F.; Tome, A.; Virtanen, A.; Vogel, A. L.; Wagner, A. C.; Wagner, P. E.; Weingartner, E.; Wimmer, D.; Winkler, P. M.; Ye, P. L.; Zhang, X.; Hansel, A.; Dommen, J.; Donahue, N. M.; Worsnop, D. R.; Baltensperger, U.; Kulmala, M.; Carslaw, K. S.; Curtius, J. Nature 2016, 533 (7604), 521-526.

(5) Crounse, J. D.; Nielsen, L. B.; Jørgensen, S.; Kjaergaard, H. G.; Wennberg, P. O. J. Phys. Chem. Lett. 2013, 4 (20), 3513-3520.

(6) Mentel, T. F.; Springer, M.; Ehn, M.; Kleist, E.; Pullinen, I.; Kurtén, T.; Rissanen, M.; Wahner, A.; Wildt, J. Atmos. Chem. Phys. 2015, 15 (12), 6745-6765.

(7) Ehn, M.; Thornton, J. A.; Kleist, E.; Sipila, M.; Junninen, H.; Pullinen, I.; Springer, M.; Rubach, F.; Tillmann, R.; Lee, B.; LopezHilfiker, F.; Andres, S.; Acir, I. H.; Rissanen, M.; Jokinen, T.; Schobesberger, S.; Kangasluoma, J.; Kontkanen, J.; Nieminen, T.; Kurten, T.; Nielsen, L. B.; Jorgensen, S.; Kjaergaard, H. G.; Canagaratna, M.; Dal Maso, M.; Berndt, T.; Petaja, T.; Wahner, A.; Kerminen, V. M.; Kulmala, M.; Worsnop, D. R.; Wildt, J.; Mentel, T. F. Nature 2014, 506 (7489), 476-479.

(8) Rissanen, M. P.; Kurtén, T.; Sipilä, M.; Thornton, J. A.; Kangasluoma, J.; Sarnela, N.; Junninen, H.; Jørgensen, S.; Schallhart, S.; Kajos, M. K.; Taipale, R.; Springer, M.; Mentel, T. F.; Ruuskanen, T.; Petäjä, T.; Worsnop, D. R.; Kjaergaard, H. G.; Ehn, M. J. Am. Chem. Soc. 2014, 136 (44), 15596-15606.

(9) Tröstl, J.; Chuang, W. K.; Gordon, H.; Heinritzi, M.; Yan, C.; Molteni, U.; Ahlm, L.; Frege, C.; Bianchi, F.; Wagner, R.; Simon, M.; Lehtipalo, K.; Williamson, C.; Craven, J. S.; Duplissy, J.; Adamov, A.; Almeida, J.; Bernhammer, A.-K.; Breitenlechner, M.; Brilke, S.; Dias, A.; Ehrhart, S.; Flagan, R. C.; Franchin, A.; Fuchs, C.; Guida, R.; Gysel, M.; Hansel, A.; Hoyle, C. R.; Jokinen, T.; Junninen, H.; Kangasluoma, J.; Keskinen, H.; Kim, J.; Krapf, M.; Kürten, A.; Laaksonen, A.; Lawler, M.; Leiminger, M.; Mathot, S.; Möhler, O.; Nieminen, T.; Onnela, A.; Petäjä, T.; Piel, F. M.; Miettinen, P.; Rissanen, M. P.; Rondo, L.; Sarnela, N.; Schobesberger, S.; Sengupta, K.; Sipilä, M.; Smith, J. N.; Steiner, G.; Tomè, A.; Virtanen, A.; Wagner, A. C.; Weingartner, E.; Wimmer, D.; Winkler, P. M.; Ye, P.; Carslaw, K. S.; Curtius, J.; Dommen, J.; Kirkby, J.; Kulmala, M.; Riipinen, I.; Worsnop, D. R.; Donahue, N. M.; Baltensperger, U. Nature 2016, 533 (7604), 527531.

(10) Jokinen, T.; Berndt, T.; Makkonen, R.; Kerminen, V.-M.; Junninen, H.; Paasonen, P.; Stratmann, F.; Herrmann, H.; Guenther, A. B.; Worsnop, D. R.; Kulmala, M.; Ehn, M.; Sipilä, M. Proc. Natl. Acad. Sci. U. S. A. 2015, 112 (23), 7123-7128.

(11) Hyttinen, N.; Kupiainen-Määttä, O.; Rissanen, M. P.; Muuronen, M.; Ehn, M.; Kurtén, T. J. Phys. Chem. A 2015, 119 (24), 6339-6345.

(12) Berndt, T.; Richters, S.; Kaethner, R.; Voigtländer, J.; Stratmann, F.; Sipilä, M.; Kulmala, M.; Herrmann, H. J. Phys. Chem. A 2015, 119 (41), 10336-10348.

(13) Crounse, J. D.; McKinney, K. A.; Kwan, A. J.; Wennberg, P. O. Anal. Chem. 2006, 78, 6726-6732.
(14) Bertram, T. H.; Kimmel, J. R.; Crisp, T. A.; Ryder, O. S.; Yatavelli, R. L. N.; Thornton, J. A.; Cubison, M. J.; Gonin, M.; Worsnop, D. R. Atmos. Meas. Tech. 2011, 4 (7), 1471-1479.

(15) Veres, P.; Roberts, J. M.; Warneke, C.; Welsh-Bon, D.; Zahniser, M.; Herndon, S.; Fall, R.; de Gouw, J. Int. J. Mass Spectrom. 2008, 274 (1), 48-55.

(16) Aljawhary, D.; Lee, A. K. Y.; Abbatt, J. P. D. Atmos. Meas. Tech. 2013, 6 (11), 3211-3224.

(17) Hansel, A.; Jordan, A.; Holzinger, R.; Prazeller, P.; Vogel, W.; Lindinger, W. Int. J. Mass Spectrom. Ion Processes 1995, 149-150 (C), 609-619.

(18) Lindinger, W.; Hansel, A.; Jordan, A. Int. J. Mass Spectrom. Ion Processes 1998, 173 (3), 191-241.

(19) Blake, R. S.; Whyte, C.; Hughes, C. O.; Ellis, A. M.; Monks, P. S. Anal. Chem. 2004, 76 (13), 3841-3845.

(20) Graus, M.; Müller, M.; Hansel, A. J. Am. Soc. Mass Spectrom. 2010, 21 (6), 1037-1044.

(21) Sulzer, P.; Hartungen, E.; Hanel, G.; Feil, S.; Winkler, K.; Mutschlechner, P.; Haidacher, S.; Schottkowsky, R.; Gunsch, D.; Seehauser, H.; Striednig, M.; Jürschik, S.; Breiev, K.; Lanza, M.; Herbig, J.; Märk, L.; Märk, T. D.; Jordan, A. Int. J. Mass Spectrom. 2014, 368, 1-5.

(22) Lindinger, W.; Hansel, A. Plasma Sources Sci. Technol. 1997, 6 (2), 111-117.

(23) De Gouw, J.; Warneke, C.; Karl, T.; Eerdekens, G.; Van der Veen, C.; Fall, R. Int. J. Mass Spectrom. 2003, 223-224, 365-382.

(24) Blake, R. S.; Monks, P. S.; Ellis, A. M. Chem. Rev. 2009, 109 (3), 861-896.

(25) Manura, D.; Dahl, D. SIMION 8.0 User Manual; Scientific Instrument Services, Inc.: Ringoes, NJ, 2008.

(26) Dotan, I. J. Chem. Phys. 1976, 65 (11), 5028-5030.

(27) Mäkelä, J. M.; Riihelä, M.; Ukkonen, A.; Jokinen, V.; Keskinen, J. J. Chem. Phys. 1996, 105 (4), 1562.

(28) Langevin, P. Ann. Chim. Phys. 1905, 5, 245-288.

(29) Chernushevich, I. V.; Loboda, A. V.; Thomson, B. A. J. Mass Spectrom. 2001, 36 (8), 849-865.

(30) Lerner, B. M.; Gilman, J. B.; Aikin, K. C.; Atlas, E. L.; Goldan, P. D.; Graus, M.; Hendershot, R.; Isaacman-VanWertz, G. A.; Koss, A.; Kuster, W. C.; Lueb, R. A.; McLaughlin, R. J.; Peischl, J.; Sueper, D.; Ryerson, T. B.; Tokarek, T. W.; Warneke, C.; Yuan, B.; de Gouw, J. A. Atmos. Meas. Tech. Discuss. 2016, 1-40.

(31) Hunter, E. P.; Lias, S. G. J. Phys. Chem. Ref. Data 1998, 27 (3), 413-656.

(32) Vlasenko, A.; Macdonald, A. M.; Sjostedt, S. J.; Abbatt, J. P. D. Atmos. Meas. Tech. 2010, 3 (4), 1055-1062.

(33) Schnitzhofer, R.; Metzger, A.; Breitenlechner, M.; Jud, W.; Heinritzi, M.; De Menezes, L. P.; Duplissy, J.; Guida, R.; Haider, S.; Kirkby, J.; Mathot, S.; Minginette, P.; Onnela, A.; Walther, H.; Wasem, A.; Hansel, A. Atmos. Meas. Tech. 2014, 7 (7), 2159-2168.

(34) Spanel, P.; Smith, D. J. Phys. Chem. 1995, 99 (42), 1555115556.

(35) Yuan, B.; Koss, A.; Warneke, C.; Gilman, J. B.; Lerner, B. M.; Stark, H.; De Gouw, J. A. Atmos. Meas. Tech. 2016, 9 (6), 2735-2752.

(36) Donahue, N. M.; Kroll, J. H.; Pandis, S. N.; Robinson, A. L. Atmos. Chem. Phys. 2012, 12 (2), 615-634.

(37) Cubison, M. J.; Jimenez, J. L. Atmos. Meas. Tech. 2015, 8 (6), 2333-2345.

(38) Kürten, A.; Rondo, L.; Ehrhart, S.; Curtius, J. Atmos. Meas. Tech. 2011, 4 (3), 437-443.

(39) Kürten, A.; Rondo, L.; Ehrhart, S.; Curtius, J. J. Phys. Chem. A 2012, 116 (24), 6375-6386.

(40) Heinritzi, M.; Simon, M.; Steiner, G.; Wagner, A. C.; Kürten, A.; Hansel, A.; Curtius, J. Atmos. Meas. Tech. 2016, 9 (4), 1449-1460. 